\title{
Differential Effect of Antioxidants Glutathione and Vitamin C on the Hepatic Injuries Induced by Plasmodium berghei ANKA Infection
}

\author{
Nayara Kauffmann $\left(\mathbb{D},{ }^{1}\right.$ Luana K. R. L. da Penha $\left(\mathbb{D},{ }^{1}\right.$ Danielle V. Braga, ${ }^{1}$ \\ Brenda J. A. Ataíde $\mathbb{D}^{1}{ }^{1}$ Nivia S. F. Mendes $\mathbb{D}^{1},{ }^{1}$ Laiane P. de Sousa $\mathbb{D}^{1},{ }^{1}$ Givago S. da Souza $\mathbb{D},{ }^{2}$ \\ Adelaide C. F. Passos $\mathbb{D}^{1}$, Evander J. O. Batista $\mathbb{D}^{3}{ }^{3}$ Anderson M. Herculano $\mathbb{D}{ }^{1}{ }^{1}$ \\ and Karen R. H. M. Oliveira $\mathbb{D}^{1,3}$ \\ ${ }^{1}$ Instituto de Ciências Biológicas, Laboratório de Neurofarmacologia Experimental, Universidade Federal do Pará, Belém, \\ Pará, Brazil \\ ${ }^{2}$ Núcleo de Medicina Tropical, Laboratório de Neurologia Tropical, Universidade Federal do Pará, Belém, Pará, Brazil \\ ${ }^{3}$ Núcleo de Medicina Tropical, Laboratório de Protozoologia, Universidade Federal do Pará, Belém, Pará, Brazil \\ Correspondence should be addressed to Karen R. H. M. Oliveira; oliveirakrm@gmail.com
}

Received 4 June 2021; Accepted 14 August 2021; Published 6 September 2021

Academic Editor: Praveen Bharti

Copyright (c) 2021 Nayara Kauffmann et al. This is an open access article distributed under the Creative Commons Attribution License, which permits unrestricted use, distribution, and reproduction in any medium, provided the original work is properly cited.

\begin{abstract}
Malaria is a life-threatening disease caused by Plasmodium and represents one of the main public health problems in the world. Among alterations associated with the disease, we highlight the hepatic impairment resulting from the generation of oxidative stress. Studies demonstrate that liver injuries caused by Plasmodium infection are associated with unbalance of the antioxidant system in hepatocytes, although little is known about the role of antioxidant molecules such as glutathione and vitamin $\mathrm{C}$ in the evolution of the disease and in the liver injury. To evaluate disease complications, murine models emerge as a valuable tool due to their similarities between the infectious species for human and mice. Herein, the aim of this study is to evaluate the effect of antioxidants glutathione and vitamin $\mathrm{C}$ on the evolution of murine malaria and in the liver damage caused by Plasmodium berghei ANKA infection. Mice were inoculated with parasitized erythrocytes and treated with glutathione and vitamin C, separately, both at $8 \mathrm{mg} / \mathrm{kg}$ during 7 consecutive days. Our data showed that during Plasmodium infection, treatment with glutathione promoted significant decrease in the survival of infected mice, accelerating the disease severity. However, treatment with vitamin $\mathrm{C}$ promoted an improvement in the clinical outcomes and prolonged the survival curve of infected animals. We also showed that glutathione promoted increase in the parasitemia rate of Plasmodium-infected animals, although treatment with vitamin $\mathrm{C}$ has induced significant decrease in parasitemia rates. Furthermore, histological analysis and enzyme biochemical measurement showed that treatment with glutathione exacerbates liver damage while treatment with vitamin $\mathrm{C}$ mitigates the hepatic injury induced by the infection. In summary, the current study provided evidences that antioxidant molecules could differently modulate the outcome of malaria disease; while glutathione aggravated the disease outcome and liver injury, the treatment with vitamin $\mathrm{C}$ protects the liver from damage and the evolution of the condition.
\end{abstract}

\section{Introduction}

Malaria represents one of the major and oldest public health problems in developing countries $[1,2]$. Despite a global fall in mortality rates since 2000 , malaria remains a worldwide problem with 228 million cases and 405.000 deaths only in 2018 [3, 4]. In endemic areas, deaths by Plasmodium infection occur as a result of severe complications which include renal failure, acidosis, cerebral malaria, respiratory distress, and severe anaemia followed by liver impairment [5-7]. 
As widely described in literature, malaria disease is caused by infection with species of Plasmodium spp. This parasite presents a complex life cycle involving different stages of development in both mosquito and human hosts $[8,9]$. Ookinetes and sporozoites are the life forms of Plasmodium found in a definitive mosquito host, and the sporozoites are responsible for infecting hepatocytes in the liver of a vertebrate host. Sporozoites reproduce asexually inside hepatocytes generating exoerythrocytic merozoites which migrate to bloodstream and infect blood erythrocytes [10, 11]. In the vertebrate host, the liver is considered a Plasmodium "depository" being an essential organ to the development of malaria disease. Malaria-associated liver injury is common in both adults and pediatric patients and is characterized by an increase in the serum levels of biochemical markers such as bilirubin and aminotransferases [12-14]. Furthermore, Kupffer cell hyperplasia, hemozoin deposition, and monocyte infiltration are also frequent histological alterations described in the malaria hepatopathy $[15,16]$.

Previous studies demonstrate that liver injuries caused by Plasmodium infection are associated with unbalance of the antioxidant system in hepatocytes [17]. However, it remains unclear if treatment with antioxidants is able to protect the liver of infected subjects. Glutathione (GSH) is the main antioxidant in intracellular environment, and the liver represents the most important provider of GSH to organs and tissues $[18,19]$. It is also widely documented that vitamin $\mathrm{C}$ acts as an essential component for liver homeostasis [20]. Although few studies have demonstrated the beneficial effect of vitamin $\mathrm{C}$ on the malaria disease, there are no studies showing the effect of this compound on the histology and biochemistry of the infected liver. Similarly, it is not evidenced if treatment with GSH can exert a protective effect in the liver of Plasmodium-infected subjects. In this context, the current study was aimed at evaluating the effect of GSH and vitamin C treatments on the malaria outcome and in the liver injury of mice infected with Plasmodium berghei ANKA $(\mathrm{PbA})$, which represent a well-established animal model of malaria $[21,22]$.

\section{Materials and Methods}

2.1. Animals. Male and female BALB/c mice (4-6 weeks old), weighing 20-25 g, were obtained from Animal Care Facilities of the Biological Sciences Institute, Federal University of Para. Animals were housed under specific pathogen-free conditions with fresh water and standard rodent food ad libitum. Mice were maintained in groups of 10 animals per cage at controlled room temperature $\left(22-24^{\circ} \mathrm{C}\right)$ in a 12 hour light/dark cycle. Experiments were carried out in agreement with Institutional Animal Ethics Committee guidelines (Protocol Number 2229290317), and all efforts were made to minimize animal suffering.

2.2. Plasmodium berghei ANKA Infection and Antioxidant Treatment. Blood aliquots containing the Plasmodium berghei ANKA ( $\mathrm{PbA})$ strain were maintained in liquid nitrogen frozen stock solutions until experimental procedures. Mice were inoculated intraperitoneally (i.p.) with $10^{6}$ parasitized red blood cells (pRBCs), suspended in $200 \mu \mathrm{l}$ of phosphatebuffered saline (PBS; pH 7.4) as previously described by Ataide et al. [23]. Treatments with GSH $(8 \mathrm{mg} / \mathrm{kg} / \mathrm{day}$ diluted in $100 \mu \mathrm{l}$ PBS $)$ or vitamin $\mathrm{C}(8 \mathrm{mg} / \mathrm{kg} /$ day diluted in $100 \mu \mathrm{l}$ PBS) were performed by i.p. injection one hour after infection with $\mathrm{PbA}$. Control mice received the same volume of sterile phosphate-buffered saline solution. The treatment was performed daily, from day 1 to day 7 postinfection. Based on the treatment, mice $(n=28)$ were randomly assigned into four groups: uninfected control, $\mathrm{PbA}$ infected mice, $\mathrm{PbA}$-infected mice $+8 \mathrm{mg} / \mathrm{kg} \mathrm{GSH}$, and $\mathrm{PbA}$ infected mice $+8 \mathrm{mg} / \mathrm{kg}$ vitamin C.

2.3. Survival Rate and Blood Parasitemia. Mice from the different groups were monitored every three days for illness clinical sign, body weight, survival rate, and blood parasitemia. Animal body weights were regularly measured during the course of the disease. PbA-infected and antioxidanttreated animals were assessed daily, and the time of death was promptly registered to determine the survival rate curve, as previously described by Oliveira et al. [24]. Parasitemia of individual mice was also measured by staining thin tail blood smears with $10 \%$ Giemsa solution (Sigma-Aldrich; diluted in PBS). Parasitemia (percentage of pRBCs) was evaluated by microscopic count and calculated as follows: [ (number of $\mathrm{pRBCs}$ )/(total numbers of RBCs counted) $\times 100$

2.4. Liver Histopathology. For histopathological analysis, at the $10^{\text {th }}$ day postinfection, $\mathrm{PbA}$-infected and treated mice were first anesthetized with a solution of ketamine $(100 \mathrm{mg} / \mathrm{kg})$ and xylazine $(10 \mathrm{mg} / \mathrm{kg})$ and euthanatized by cervical dislocation as previously described by Okokon et al. [25]. The liver was aseptically collected by total hepatectomy, and samples were fixed in Bouin's solution (picric acid, $750 \mathrm{ml}$; formaldehyde, $250 \mathrm{ml}$; and acetic acid, $5 \mathrm{ml}$ ) for 48 hours. Then, they were progressively dehydrated with increased concentration of alcohol $(70 \%, 80 \%, 90 \%, 95 \%$, and $100 \%$ ) for 40 minutes each. Subsequently, the samples were diaphanized in xylol twice for 30 minutes and paraffinized $\left(58-60^{\circ} \mathrm{C}\right)$ for 60 minutes, forming paraffin blocks. Finally, the tissue blocks were cut with the aid of a microtome at a thickness of $5 \mu \mathrm{m}$, followed by the assembly of histological slides. Then, deparaffinization was performed for 24 hours in a drying oven at $56^{\circ} \mathrm{C}$, followed by hydration of the cuts through a sequence baths in xylol I, xylol II, absolute alcohol I, absolute alcohol II, and alcohol 95\%, 90\%, $80 \%$, and $70 \%$ for three minutes each and distilled water for five minutes each. Slides were then stained with hematoxylin for 5 minutes and counterstained with eosin for one minute and, after successive washes, mounted on Permount (Fisher Scientific).

Liver sections were visualized under a light microscope (Nikon, Eclipse E800 Yokohama, Japan) and photographed at 200x magnification. Histological alterations in the tissue were semiquantitatively scored as described previously by Viriyavejakul et al. [26]. Briefly, double-blind analysis was performed in order to determinate the presence of steatosis, hyperplasic Kupffer cells, sinusoidal congestion, 


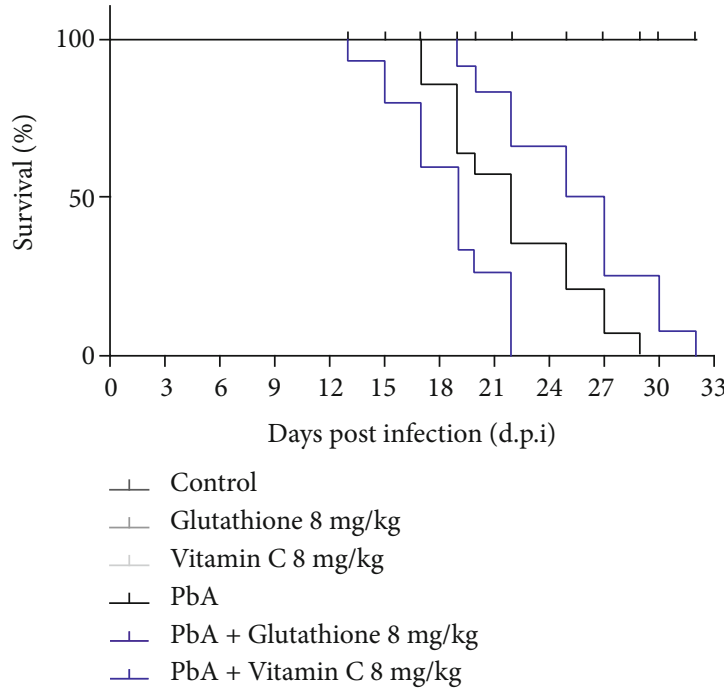

(a)

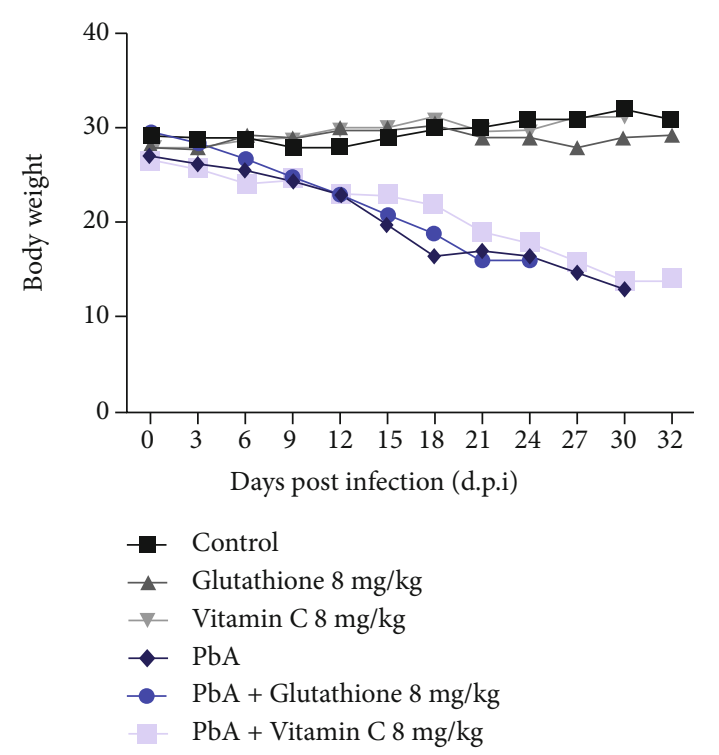

(b)

Figure 1: Glutathione and vitamin C treatments modify the survival curve of Plasmodium berghei ANKA-infected animals: (a) glutathione and vitamin $\mathrm{C}$ were administrated, intraperitoneally, at $8 \mathrm{mg} / \mathrm{kg}$ for 7 consecutive days, and survival curve analysis was carried out by using the Mantel-Cox logrank test ( $p \leq 0.05)$; (b) body weight variation between groups during the infection (\%). Results are representative of three independent experiments. Results shown are mean \pm SD.

and hemozoin deposition. Each parameter was graded on a scale from 0 to 3 : $0=$ absent, $1=$ mild, $2=$ moderate, and $3=$ severe. The total liver alteration score was expressed as the sum of the scores for each parameter with 12 being the maximum.

2.5. Biochemical Parameters of Liver Injury. The hepatocellular injury was assessed by evaluation of serum biomarkers of liver damage such as alanine aminotransferase (ALT), aspartate aminotransferase (AST), and total and direct bilirubin (BT and BD). Briefly, at the $10^{\text {th }}$ day postinfection, PbAinfected and treated animals were properly anesthetized and blood samples were collected by cardiac puncture. After centrifugation (3500 rpm for 10 minutes), the supernatant was removed and stored in a low-temperature freezer at $80^{\circ} \mathrm{C}$ until the biochemical test. Serum biochemical assays were conducted in accordance with the commercial kit instructions and determined in a spectrophotometer at a wavelength of $340 \mathrm{~nm}$.

2.6. Statistical Analysis. Kaplan-Meier curves were generated for survival data, and significance was assessed by the Mantel-Cox logrank test. Parasitemia values were fitted by a linear function using the least square methods, and one-way ANOVA was conducted to determine the difference among the groups. Adjusted $p$ values were calculated for multiplicity using the Bonferroni correction $(p=0.05 / 3)$. The level of plasma enzymes was expressed as the mean \pm standard deviation (SD) and compared by two-way ANOVA, using Tukey-Kramer analysis as the posttest. All data were plotted and analyzed using the GraphPad Prism software (version 6.0 ), and $p<0.05$ was considered statistically significant.
All data are representative of at least three independent experiments.

\section{Results}

3.1. GSH and Vitamin C Treatments Modify the Survival Curve and Parasitemia Rate of PbA-Infected Mice. To describe the effect of GSH and vitamin $\mathrm{C}$ on the clinical progression of $\mathrm{PbA}$-infected mice, animals were treated with $8 \mathrm{mg} / \mathrm{kg} /$ day of GSH and vitamin C, separately, for 7 consecutive days. As expected, during $\mathrm{PbA}$ infection, $\mathrm{BALB} / \mathrm{c}$ mice developed characteristic clinical manifestations such as anemia, hepatosplenomegaly, and physic inactivity between the $17^{\text {th }}$ and $29^{\text {th }}$ days postinfection.

Our data showed that during $\mathrm{PbA}$ infection, nontreated animals were able to survive until 29 days postinfection; however, the treatment with $8 \mathrm{mg} / \mathrm{kg} \mathrm{GSH}$ promoted a significant decrease in the survival of $\mathrm{PbA}$-infected mice, with animals dying between days 17 and 19 postinfection (d.p.i). Furthermore, we also observed that $100 \%$ of $\mathrm{PbA}$ infected animals treated with GSH died in the $23^{\text {rd }}$ d.p.i. while the $\mathrm{PbA}$-infected group survived until the $29^{\text {th }}$ d.p.i. (Figure 1(a)).

On the other hand, vitamin $\mathrm{C}$ treatment promoted an improvement in the disease clinical outcomes and expanded the survival time of the $\mathrm{PbA}$-infected group. Figure 1(a) demonstrates that $50 \%$ of animals treated with $8 \mathrm{mg} / \mathrm{kg}$ vitamin $\mathrm{C}$ died between the $25^{\text {th }}$ and $27^{\text {th }}$ d.p.i. and $100 \%$ only at the $34^{\text {th }}$ d.p.i. Further, GSH and vitamin $\mathrm{C}$ also had no effect on body weight average in $\mathrm{PbA}$-infected mice and $\mathrm{PbA}$ infected animals treated with antioxidants (Figure 1(b)). 
Our results have also shown that $8 \mathrm{mg} / \mathrm{kg}$ GSH promoted a fast and time-dependent increase in parasitemia values in $\mathrm{PbA}$-infected animals (Figure 2). On the other hand, treatment with $8 \mathrm{mg} / \mathrm{kg}$ vitamin $\mathrm{C}$ has induced significant decrease in parasitemia values when compared with the nontreated $\mathrm{PbA}$-infected group. This differential effect exerted by GSH and vitamin $\mathrm{C}$ can be better evidenced by mathematical analysis of parasitemia curve time evolution. As observed in Figure 2, $\mathrm{PbA}$-infected animals which were treated with $8 \mathrm{mg} / \mathrm{kg}$ GSH or $8 \mathrm{mg} / \mathrm{kg}$ vitamin C present elevated and decreased values of the parasitemia saturation coefficient (1.46 and 1.09, respectively) when compared with the nontreated $\mathrm{PbA}$-infected group (1.28).

\subsection{GSH and Vitamin C Treatment, Respectively, Exacerbated} and Attenuated Hepatic Histopathology Induced by $\mathrm{PbA}$ Infection in Mice. To characterize liver histopathological alterations in $\mathrm{PbA}$-infected animals treated with $8 \mathrm{mg} / \mathrm{kg}$ glutathione or $8 \mathrm{mg} / \mathrm{kg}$ vitamin $\mathrm{C}$, we performed the hematoxylineosin staining (Figure 3). As shown in Figure 3, liver tissue sections from uninfected mice and uninfected mice treated with $8 \mathrm{mg} / \mathrm{kg} \mathrm{GSH}$ or $8 \mathrm{mg} / \mathrm{kg}$ vitamin C had no morphological alterations, showing normal cellular architecture with distinct hepatic cells, sinusoidal spaces, and central veins. In $\mathrm{PbA}$-infected animals, the sinusoidal area presented more enlargements, with deposition of hemozoin malaria pigment inside hyperplasic Kupffer cells and few spots with a discreet steatosis (Figure 3).

However, liver histopathological analysis of $\mathrm{PbA}$ infected mice treated with $8 \mathrm{mg} / \mathrm{kg}$ GSH showed a more disarrangement of normal hepatic cells with hyperplasia and polymorphonuclear aggregation with increased numbers of inflammatory cells and vascular congestions (Figure 3). Increased cell infiltration including lymphocytes, mononuclear cells, and neutrophils was observed in the liver of $\mathrm{PbA}$-infected mice treated with $8 \mathrm{mg} / \mathrm{kg} \mathrm{GSH}$ on day 10 postinfection, leading to severe inflammation and tissue damage as evidenced in double-blind histological evaluation (Table 1). In contrast, animals treated with $8 \mathrm{mg} / \mathrm{kg}$ vitamin $\mathrm{C}$ presented less disarrangement of normal hepatic cells with few hyperplasia and polymorphonuclear aggregation, decreased numbers of inflammatory cells, and vascular congestions in comparison with nontreated $\mathrm{PbA}$-infected mice. Vitamin C also decreased cell infiltration including lymphocytes, mononuclear cells, and neutrophils decreasing inflammatory response and liver damage in infected animals (Table 1).

\subsection{Biochemical Measure of Liver Injuries in PbA-Infected} Mice Treated with GSH and Vitamin C. To further assess functional changes, biochemical parameters of liver function were evaluated in the serum of uninfected control mice and $\mathrm{PbA}$-infected mice treated with GSH or vitamin C. As shown in Figure 4, $\mathrm{PbA}$-infected mice exhibited significant increase in serum AST, ALT, BD, and BT levels compared with the uninfected group (Figure 4). Moreover, PbAinfected mice treated with $8 \mathrm{mg} / \mathrm{kg}$ GSH showed elevated levels of serum AST, ALT, BD, and BT in comparison with both control and $\mathrm{PbA}$-infected mice. However, our data

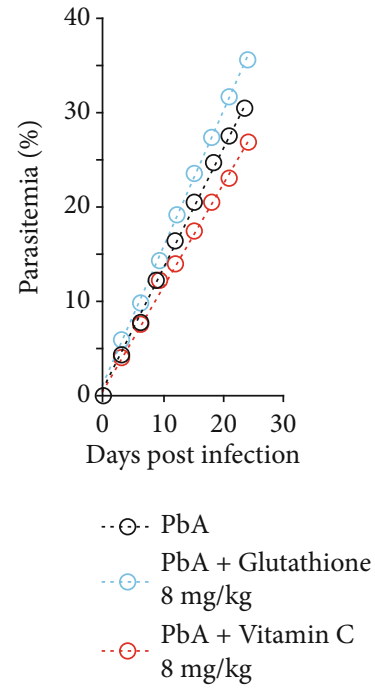

Figure 2: Course of Plasmodium berghei parasitemia in BALB-C mice treated with glutathione and vitamin C. Peripheral blood parasitemia was assessed by Giemsa staining. Parasitemia levels were measured as the number of parasitized red blood cells (pRBCs) in at least 1000 RBCs (two-way ANOVA; $p=0.05 / 3$ ).

have also shown that $\mathrm{PbA}$-infected animals treated with vitamin $C$ presented markedly reduced serum levels of AST, ALT, BD, and BT similar to those observed in the noninfected group (Figure 4), demonstrating that the treatment with vitamin $\mathrm{C}$ protects the liver from $\mathrm{PbA}$ infection injury.

\section{Discussion}

The current study demonstrated that treatment with antioxidants GSH and vitamin C induces a distinct effect on liver injuries caused by malaria infection. Results demonstrated that treatment with GSH accelerates the evolution of the disease in $\mathrm{PbA}$-infected mice as well as the liver damage, while the treatment with vitamin $\mathrm{C}$ controls the disease outcome and mitigates the hepatotoxicity associated with the condition. It is widely described in literature that human malaria is characterized by intense hepatotoxicity and liver dysfunction, and although hepatic dysfunction in malaria is not fully understood, oxidative stress is often related to this condition [17]. As demonstrated in both human patients and animals models, liver damage during Plasmodium infection occurs as a result of free heme accumulation that triggers severe oxidative stress and stimulates proinflammatory response by tumor necrosis factor (TNF- $\alpha$ ) release [27-29].

During malaria infection, liver dysfunction is often associated with elevated values of blood parasitemia [30-32], and data presented in our study show that mice infected with Plasmodium berghei ANKA demonstrated a time-dependent increase in parasitemia rates as well as intense liver damage as demonstrated by biochemical measurement (AST, ALT, and bilirubin levels). This is in agreement with the literature which describes a positive 

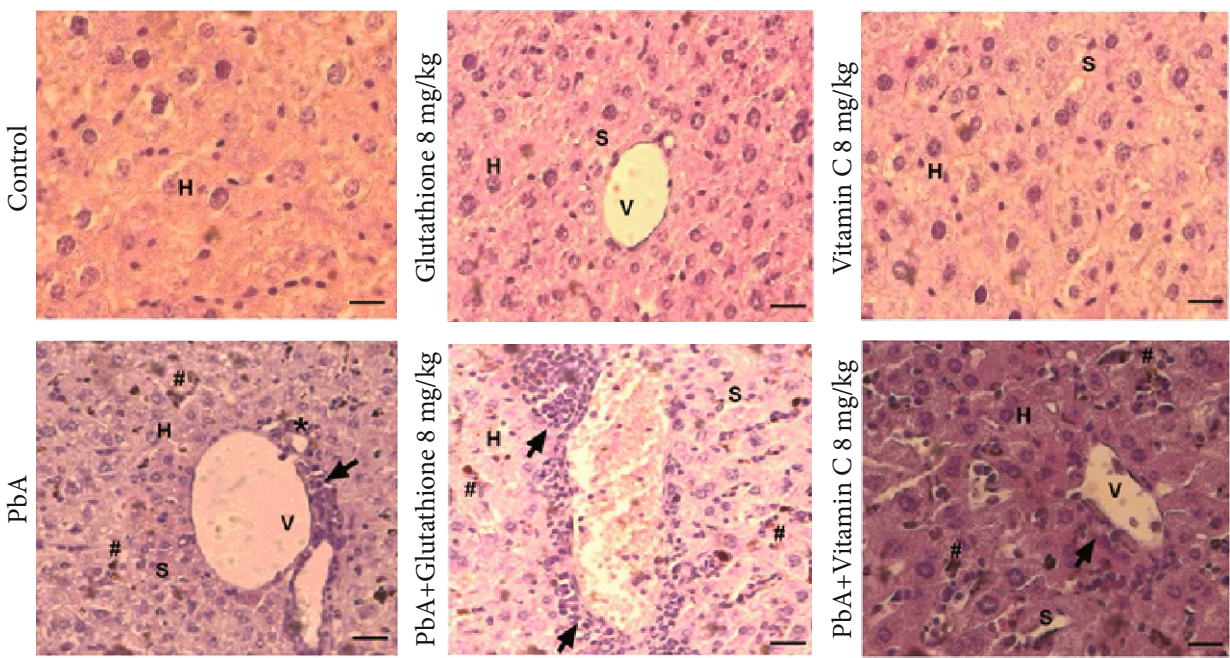

Figure 3: Histological alteration into the liver tissue of PbA-infected mice treated with glutathione and vitamin C. Representative light microphotographs from the liver of mice at day 10 postinfection and stained with $\mathrm{H} \& \mathrm{E}(\times 20$ objective lens). Liver from uninfected mice (control group) with normal histological appearance and $\mathrm{PbA}$-infected mice showing cellular infiltration (arrows) and vacuolation (asterisk) (bars, $20 \mu \mathrm{m})$. H: hepatocytes; S: sinusoid; \#: hemozoin.

TABle 1: Histopathological grading of liver lesions at 10 days post-Plasmodium berghei ANKA infection.

\begin{tabular}{|c|c|c|c|c|c|c|}
\hline \multirow[b]{2}{*}{ Histological changes } & \multicolumn{6}{|c|}{ Histopathologic grading } \\
\hline & Control & $\begin{array}{l}\text { Glutathione } \\
(8 \mathrm{mg} / \mathrm{kg})\end{array}$ & $\begin{array}{l}\text { Vitamin C } \\
(8 \mathrm{mg} / \mathrm{kg})\end{array}$ & $\mathrm{PbA}$ & $\begin{array}{l}\mathrm{PbA}+\text { glutathione } \\
\quad(8 \mathrm{mg} / \mathrm{kg})\end{array}$ & $\begin{array}{l}\mathrm{PbA}+\text { vitamin } \mathrm{C} \\
\quad(8 \mathrm{mg} / \mathrm{kg})\end{array}$ \\
\hline Fatty change & 1 & 1 & 0 & 0 & 0 & 0 \\
\hline Kupffer cells & 0 & 0 & 0 & 2 & 3 & 1 \\
\hline Sinusoid congestion & 0 & 0 & 0 & 2 & 3 & 1 \\
\hline Hemozoin deposition & 0 & 0 & 0 & 2 & 3 & 1 \\
\hline $\begin{array}{l}\text { Portal tract } \\
\text { inflammation }\end{array}$ & 0 & 0 & 0 & 3 & 3 & 2 \\
\hline Bile duct proliferation & 0 & 0 & 0 & 2 & 3 & 2 \\
\hline Total histological score & $1 / 18$ & $1 / 18$ & $0 / 18$ & $11 / 18$ & $15 / 18$ & $7 / 18$ \\
\hline
\end{tabular}

correlation between malaria hepatopathy and the activation of liver macrophages that phagocytize haemozoin or parasitized erythrocytes [12]. Our findings are also supported by previous studies demonstrating that the animal model represents a powerful and valuable tool to evaluate tissue and organ dysfunctions elicited by malaria [33, 34].

Data presented in our study have demonstrated that GSH treatment has favored infection and increased liver toxicity in PbA-infected mice. Although GSH represents an important antioxidant molecule in distinct tissue and organs, there are strong evidences demonstrating that species of the Plasmodium genus use GSH as a substrate for their reproduction in the vertebrate host [35-37]. Our results are in agreement with these reports since GSH treatment has induced a fast increase in parasitemia values; also, it has decreased animal survival in the PbA-infected group. Indeed, histological and biochemical evaluation in $\mathrm{PbA}$ infected animals gives us strong evidences that GSH treatment exacerbates liver damage elicited by Plasmodium infection. Although more studies should be performed, these findings have relevant clinical implications for populations living in endemic malaria areas which largely use precursor of GSH synthesis such as acetylcysteine for the treatment of liver injuries.

While GSH treatment has favored $\mathrm{PbA}$ infection and liver impairment, our data also demonstrated that the treatment with vitamin $\mathrm{C}$ has a host beneficial effect in mice developing malaria. Anterior studies have already shown that vitamin $\mathrm{C}$ exerts a protective action in Plasmodiuminfected animals [38-40]. Our study demonstrates that vitamin $\mathrm{C}$ treatment attenuates parasitemia evolution and prevents liver damage induced by malaria. Evidence of hepatic damage in the current study included events such as inflammation in the portal tract, hemozoin deposition, sinusoid congestion, and hyperplasia of Kupffer cells, and treatment with vitamin $\mathrm{C}$ proved to be effective in preventing these events. Our data are in accordance with previous reports which demonstrate the preventive effect of vitamin $\mathrm{C}$ on the hepatocytes in different models of liver injuries [41-43]. It is also well reported that alterations in the redox status of the liver is a mediating phenomenon of Plasmodium infection [44-46]. In this context, we hypothesized 


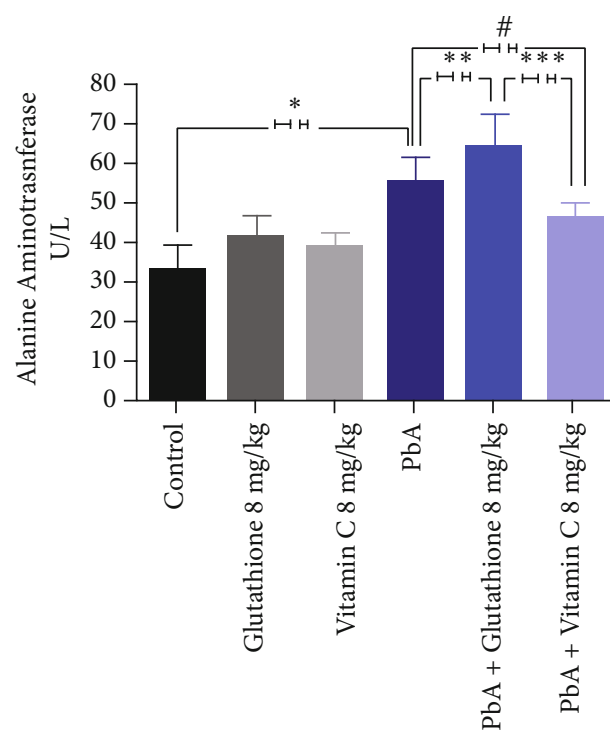

(a)

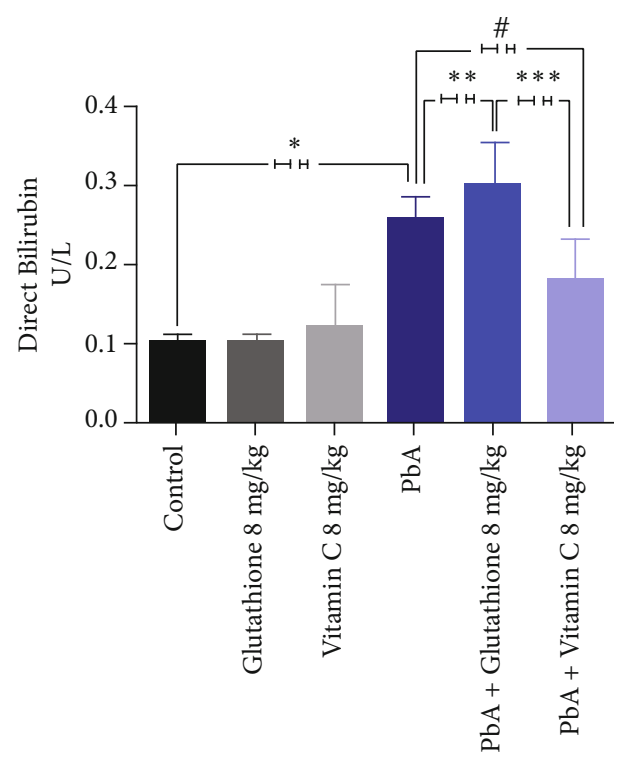

(c)

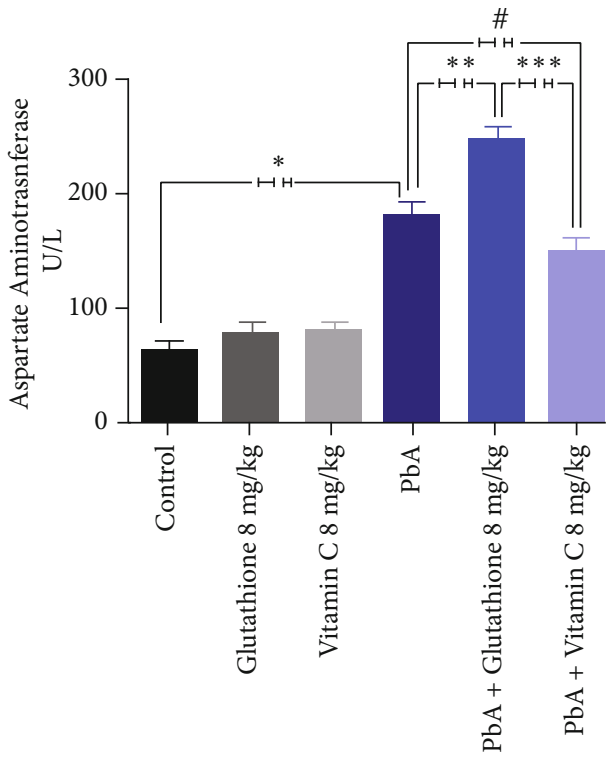

(b)

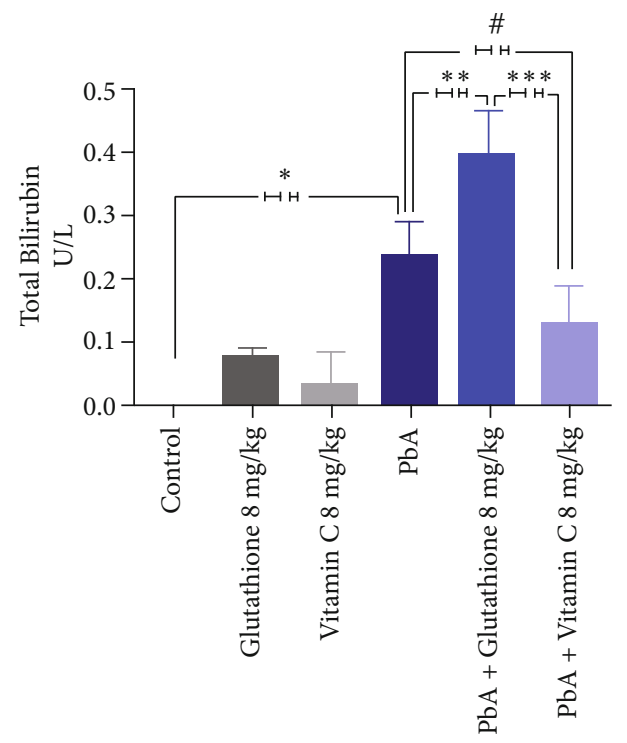

(d)

Figure 4: Liver enzyme activity in BALB-C mice infected with Plasmodium berghei ANKA and treated with glutathione and vitamin C. Alanine aminotransferase (a), aspartate aminotransferase (b), total bilirubin (c), and direct bilirubin (d) activities were determined 10 days postinfection in the serum of control uninfected animals, $\mathrm{PbA}$-infected mice, and $\mathrm{PbA}$-infected animals treated with glutathione and vitamin C. Data are presented as means \pm SD with $p \leq 0.05$.

that vitamin $\mathrm{C}$ prevents liver damage in $\mathrm{PbA}$-infected mice by avoiding oxidative stress induced by parasite infection.

Taken together, the data presented in the current study let us hypothesize that during Plasmodium infection, GSH and vitamin $\mathrm{C}$ are differently used in the host-parasite relation. In other words, while GSH could favor parasite reproduction and their life cycle, vitamin $\mathrm{C}$ acts preferentially in the host as a liver protective molecule.

\section{Conclusions}

In conclusion, this study demonstrated that, in BALB-C mice, the Plasmodium berghei ANKA strain induces a chronic infection and liver damage which could be differently modulated by the use of antioxidants. The treatment with GSH aggravated the disease outcome and liver injury, and, on the other hand, the treatment with vitamin $\mathrm{C}$ protects the liver from damage and the evolution of the disease.

\section{Data Availability}

The raw data supporting the conclusions of this manuscript will be made available by the authors, without undue reservation, to any qualified researcher. 


\section{Conflicts of Interest}

The authors declare that they have no competing interests.

\section{Authors' Contributions}

Nayara Kauffmann performed and acquired all the experimental data. Luana K. R. L. da Penha performed the infection procedures. Danielle V. Braga performed and analyzed the biochemical data. Brenda J. de A. Ataíde performed the histological analyses. Nívia de S. F. Mendes performed the histological analyses. Laiane P. de Sousa performed the infection procedures. Givago da S. Souza performed and analyzed statistical data. Adelaide da C. F. Passos revised the manuscript and statistical analysis. Evander de J. O. Batista contributed to the article final drafting. Anderson M. Herculano analyzed and interpreted the data. Karen R. H. M. Oliveira conceived, designed, and supervised the study.

\section{Acknowledgments}

This work was supported by grants from CAPES and CNPq.

\section{References}

[1] A. A. Escalante and M. A. Pacheco, "Malaria molecular epidemiology: an evolutionary genetics perspective," Microbiology Spectrum, vol. 7, no. 4, 2019.

[2] R. Varo, C. Chaccour, and Q. Bassat, "Actualizacion en malaria," Medicina Clínica (Barcelona), vol. 155, no. 9, pp. 395-402, 2020.

[3] WHO, World Malaria Report, World Health Organization, 2019.

[4] S. L. Rei Yan, F. Wakasuqui, C. Wrenger, and C. Wrenger, "Point-of-care tests for malaria: speeding up the diagnostics at the bedside and challenges in malaria cases detection," Diagnostic Microbiology and Infectious Disease, vol. 98, no. 3, p. $115122,2020$.

[5] G. D. Shanks, "Historical review: problematic malaria prophylaxis with quinine," The American Journal of Tropical Medicine and Hygiene, vol. 95, no. 2, pp. 269-272, 2016.

[6] J. H. Im, H. Y. Kwon, J. Baek et al., "Severe Plasmodium vivax infection in Korea," Malaria Journal, vol. 16, no. 1, p. 51, 2017.

[7] F. Val, S. Avalos, A. A. Gomes et al., "Are respiratory complications of Plasmodium vivax malaria an underestimated problem?," Malaria Journal, vol. 16, no. 1, p. 495, 2017.

[8] A. Rossati, O. Bargiacchi, V. Kroumova, M. Zaramella, A. Caputo, and P. L. Garavelli, "Climate, environment and transmission of malaria," Le Infezioni in Medicina, vol. 24, no. 2, pp. 93-104, 2016.

[9] S. Muller, "Role and regulation of glutathione metabolism in Plasmodium falciparum," Molecules, vol. 20, no. 6, pp. 10511-10534, 2015.

[10] U. Frevert, S. Engelmann, S. Zougbede et al., "Intravital observation of Plasmodium berghei sporozoite infection of the liver," PLoS Biology, vol. 3, no. 6, p. e192, 2005.

[11] D. Scaccabarozzi, K. Deroost, Y. Corbett et al., "Differential induction of malaria liver pathology in mice infected with Plasmodium chabaudi AS or Plasmodium berghei NK65," Malaria Journal, vol. 17, no. 1, p. 18, 2018.
[12] S. A. Mikolajczak, A. M. Vaughan, N. Kangwanrangsan et al., "Plasmodium vivax liver stage development and hypnozoite persistence in human liver-chimeric mice," Cell Host \& Microbe, vol. 17, no. 4, pp. 526-535, 2015.

[13] R. Raphemot, D. Posfai, and E. R. Derbyshire, "Current therapies and future possibilities for drug development against liver-stage malaria," The Journal of Clinical Investigation, vol. 126, no. 6, pp. 2013-2020, 2016.

[14] K. E. Rankin, S. Graewe, V. T. Heussler, and R. R. Stanway, "Imaging liver-stage malaria parasites," Cellular Microbiology, vol. 12, no. 5, pp. 569-579, 2010.

[15] M. S. Nobes, H. Ghabrial, K. M. Simms, R. B. Smallwood, D. J. Morgan, and R. B. Sewell, "Hepatic Kupffer cell phagocytotic function in rats with erythrocytic-stage malaria," Journal of Gastroenterology and Hepatology, vol. 17, no. 5, pp. 598-605, 2002.

[16] A. B. Rupani and A. D. Amarapurkar, "Hepatic changes in fatal malaria: an emerging problem," Annals of Tropical Medicine and Parasitology, vol. 103, no. 2, pp. 119-127, 2009.

[17] J. Delhaye, O. Glaizot, and P. Christe, "The effect of dietary antioxidant supplementation in a vertebrate host on the infection dynamics and transmission of avian malaria to the vector," Parasitology Research, vol. 117, no. 7, pp. 2043-2052, 2018.

[18] C. L. U. Shelly, "Glutathione synthesis," Biochimica et Biophysica Acta, vol. 1830, no. 5, pp. 3143-3153, 2013.

[19] J. Vega-Rodríguez, R. Pastrana-Mena, K. N. Crespo-Lladó, J. G. Ortiz, I. Ferrer-Rodríguez, and A. E. Serrano, "Implications of glutathione levels in the Plasmodium berghei response to chloroquine and artemisinin," PLoS One, vol. 10, no. 5, article e0128212, 2015.

[20] M. Esmaeilizadeh, M. Hosseini, F. Beheshti et al., "Vitamin C improves liver and renal functions in hypothyroid rats by reducing tissue oxidative injury," International Journal for Vitamin and Nutrition Research, vol. 90, no. 1-2, pp. 84-94, 2020.

[21] S. Bagot, M. I. Boubou, S. Campino et al., "Susceptibility to experimental cerebral malaria induced by Plasmodium berghei ANKA in inbred mouse strains recently derived from wild stock," Infection and Immunity, vol. 70, no. 4, pp. 2049-2056, 2002.

[22] V. Combes, J. B. De Souza, L. Rénia, N. H. Hunt, and G. E. Grau, "Cerebral malaria: which parasite? Which model?," Drug Discovery Today: Disease Models, vol. 2, no. 2, pp. 141147, 2005.

[23] B. J. A. Ataide, N. Kauffmann, N. S. F. Mendes et al., "Melatonin prevents brain damage and neurocognitive impairment induced by Plasmodium berghei ANKA infection in murine model of cerebral malaria," Frontiers in Cellular and Infection Microbiology, vol. 10, p. 541624, 2020.

[24] K. R. H. M. Oliveira, N. Kauffmann, L. K. R. Leão et al., “Cerebral malaria induces electrophysiological and neurochemical impairment in mice retinal tissue: possible effect on glutathione and glutamatergic system," Malaria Journal, vol. 16, no. 1, p. 440, 2017.

[25] J. E. Okokon, J. O. Simeon, and E. E. Umoh, "Hepatoprotective activity of the extract of Homalium letestui stem against paracetamol-induced liver injury," Avicenna J Phytomed., vol. 7, no. 1, pp. 27-36, 2017.

[26] P. Viriyavejakul, V. Khachonsaksumet, and C. Punsawad, "Liver changes in severe Plasmodium falciparum malaria: 
histopathology, apoptosis and nuclear factor kappa B expression," Malaria Journal., vol. 13, no. 1, 2014.

[27] S. Dey, S. Bindu, M. Goyal et al., "Impact of intravascular hemolysis in malaria on liver dysfunction: involvement of hepatic free heme overload, NF- $\kappa \mathrm{B}$ activation, and neutrophil infiltration," The Journal of Biological Chemistry, vol. 287, no. 32, pp. 26630-26646, 2012.

[28] S. Percário, D. R. Moreira, B. A. Q. Gomes et al., "Oxidative stress in malaria," International Journal of Molecular Sciences, vol. 13, no. 12, pp. 16346-16372, 2012.

[29] T. N. Nguyen, S. Baaklini, F. Koukouikila-Koussounda et al., "Association of a functional TNF variant with Plasmodium falciparum parasitaemia in a Congolese population," Genes and Immunity, vol. 18, no. 3, pp. 152-157, 2017.

[30] A. M. Vaughan and S. H. I. Kappe, "Malaria parasite liver infection and exoerythrocytic biology," Cold Spring Harbor Perspectives in Medicine, vol. 7, no. 6, article a025486, 2017.

[31] P. D. S. Ventura, C. P. F. Carvalho, N. M. T. Barros et al., "Malaria infection promotes a selective expression of kinin receptors in murine liver," Malaria Journal, vol. 18, no. 1, p. 213, 2019.

[32] A. Odedra, L. Webb, L. Marquart et al., "Liver function test abnormalities in experimental and clinical Plasmodium vivax infection," The American Journal of Tropical Medicine and Hygiene, vol. 103, no. 5, pp. 1910-1917, 2020.

[33] H. C. Van Der Heyde, P. Bauer, G. Sun et al., "Assessing vascular permeability during experimental cerebral malaria by a radiolabeled monoclonal antibody technique," Infection Immunity., vol. 69, no. 5, pp. 3460-3465, 2001.

[34] T. Taniguchi, E. Miyauchi, S. Nakamura et al., "Plasmodium berghei ANKA causes intestinal malaria associated with dysbiosis," Nature, vol. 5, p. 15699, 2015.

[35] V. Padín-Irizarry, E. E. Colón-Lorenzo, J. Vega-Rodríguez et al., "Glutathione-deficient_Plasmodium berghei_parasites exhibit growth delay and nuclear DNA damage," Free Radical Biology and Medicine, vol. 95, pp. 43-54, 2016.

[36] E. Jortzik and K. Becker, "Thioredoxin and glutathione systems in _Plasmodium falciparum_," International Journal of Medical Microbiology, vol. 302, no. 4-5, pp. 187-194, 2012.

[37] G. Kapoor and H. S. Banyal, "Glutathione reductase and thioredoxin reductase: novel antioxidant enzymes from Plasmodium berghei," The Korean Journal Parasitology, vol. 47, no. 4, pp. 421-424, 2009.

[38] X. Qin, J. Liu, Y. Du et al., "Different doses of vitamin C supplementation enhances the Th1 immune response to early Plasmodium yoelii 17XL infection in BALB/c mice," International Immunopharmacology, vol. 70, pp. 387-395, 2019.

[39] M. Z. Rahfiludin and P. Ginandjar, "The effect of zinc and vitamin $C$ supplementation on hemoglobin and hematocrit levels and immune response in patients with Plasmodium vivax malaria," The Southeast Asian Journal of Tropical Medicine and Public Health, vol. 44, no. 5, pp. 733-739, 2013.

[40] I. Mgbemena and C. Ifeyinwa, "The efficacy of antioxidant (vitamin C) in the treatment and management of malaria," Advances in Biotechnology \& Microbiology, vol. 15, no. 4, p. 555919, 2020.

[41] M. Su, X. Liang, X. Xu, X. Wu, and B. Yang, "Hepatoprotective benefits of vitamin $\mathrm{C}$ against perfluorooctane sulfonateinduced liver damage in mice through suppressing inflammatory reaction and ER stress," Environmental Toxicology and Pharmacology, vol. 65, pp. 60-65, 2019.
[42] M. Su, H. Chen, C. Wei, N. Chen, and W. Wu, "Potential protection of vitamin C against liver-lesioned mice," International Immunopharmacology, vol. 22, no. 2, pp. 492-497, 2014.

[43] Y. Okamura, A. Omori, N. Asada, and A. Ono, "Effects of vitamin $\mathrm{C}$ and $\mathrm{E}$ on toxic action of alcohol on partial hepatectomyinduced liver regeneration in rats," Journal of Clinical Biochemistry and Nutrition, vol. 63, no. 1, pp. 50-57, 2018.

[44] K. Deroost, N. Lays, T. Pham et al., "Hemozoin induces hepatic inflammation in mice and is differentially associated with liver pathology depending on the Plasmodium strain," PLoS One, vol. 9, no. 11, 2014.

[45] M. A. Dkhil, E. M. Al-Shaebi, and S. Al-Quraishy, "Effect of Indigofera oblongifolia on the hepatic oxidative status and expression of inflammatory and apoptotic genes during blood-stage murine malaria," Oxidative Medicine and Cellular Longevity, vol. 2019, Article ID 8264861, 7 pages, 2019.

[46] A. Sengupta, A. Basant, S. Ghosh, S. Sharma, and H. M. Sonawat, "Liver metabolic alterations and changes in host intercompartmental metabolic correlation during progression of malaria," Journal of Parasitology Research, vol. 2011, Article ID 901854, 14 pages, 2011. 